REPORTS OF MORPHOLOGY
$\begin{gathered}\text { Official Journal of the Scientific Society of Anatomists, } \\ \text { Histologists, Embryologists and Topographic Anatomists } \\ \text { of Ukraine } \\ \text { journal homepage: https://morphology-journal.com }\end{gathered}$

\title{
Changes in the asymmetric dimethylarginine and endothelial nitric oxide synthase levels in pathogenesis of experimental diabetic retinopathy
}

Sirman Ya.V., Savytskyi I.V., Preys N.I.

Ukrainian Research and Development Institute for Transport Medicine of the Ministry of Health of Ukraine, State-Owned Enterprise

\section{ARTICLE INFO}

Received: 4 August, 2020

Accepted: 8 September, 2020

UDC: $616-092: 617.735: 161.379-$

0008.64:612.08

\section{CORRESPONDING AUTHOR}

e-mail: farmakod@ukr.net Savytskyi I.V.
Endothelial dysfunction associated with impaired nitric oxide excretion plays an important role in the onset and progression of diabetic retinopathy. It has been proven that a decrease in the activity of endothelial NO-synthase (eNO-S), the inhibitor of which is asymmetric dimethylarginine (ADMA), plays an important role in this. Objective: to study the level of asymmetric dimethylarginine and endothelial nitric oxide synthase at different stages of development of diabetic retinopathy in the experiment. The study was conducted in Wistar white rats of 180-200 g weight. According to the tasks, the animals were separated into 2 groups as follows: group 1 - 60 intact animals, group 2 - 60 animals with simulated diabetic retinopathy without further correction. Type 2 diabetes mellitus and diabetic retinopathy were simulated through intraperitoneal administration of Streptozotocin (Sigma, USA) diluted in 0.1M citrate buffer with $\mathrm{pH}=4.5$. Streptozotocin dose of $55 \mathrm{mg}$ per $\mathrm{kg}$ of animal weight was divided into two administrations. The streptozotocin intake was preceded by a 28-day high-fat diet. Our study showed impaired endothelial function in diabetic retinopathy, as evidenced by an increased ADMA level $(p<0.001)$. We have determined a stepwise increase of asymmetric dimethylarginine level in blood of rats with simulated pathology which is apparent in its highest at phase 3. Pathogenetic effect of increased ADMA on eNO-S activity was verified at all experimental stages, Impairment of physiological nitric oxide synthesis in simulated pathology has been proved as evidenced by reduced activity of endothelial NO-synthase yet on the 30th day with further negative dynamics up to the 180 th day $(p<0.001$ compared with the intact group findings).

Keywords: diabetic retinopathy, endothelial dysfunction, asymmetric dimethylarginine, endothelial NO-synthase, comparative description.

\section{Introduction}

Endothelial dysfunction which is associated with impaired secretion of nitric oxide is an essential link in pathogenesis of diabetes mellitus and plays the key role in occurrence and progression of diabetic retinopathies $[14,39]$. Reduction of endothelium-dependent vasodilatation is also reported in atherosclerosis progression [23]. Depression of the endothelial nitric oxide synthase activity has impact both on essential and secondary hypertensions [26]. Impairments in nitric oxide metabolism occur both through lack of substrate in the form of arginine in the endothelial cells and activation of its inhibitors. Hence, depression of endothelial NO-synthase activity in many cases is explained by accumulation of methylated arginine derivatives which are inhibitors to the above enzyme. Asymmetric dimethylarginine (ADMA) is the most typical among these inhibitors [11]. It should be also noted that symmetric dimethylarginine is not an NOsynthase inhibitor [23, 28, 39]. The major pathophysiologic effect of ADMA and homocysteine is depression of the endothelium-dependent vasodilatation. This process depends on some factors but first of all on reduction of nitric oxide synthesis in the endothelial cells and restriction of accessibility to muscular guanylate cyclase for it. It was firstly proved in 1992 that ADMA, in contrast to other methylated arginine derivatives, was an endogenous inhibitor of nitric oxide synthesis [33, 36, 37, 39]. It is proved that ADMA injection causes high hypertension [1].

L-arginine-NO transformation occurs with direct 
involvement of endothelial NO-synthase (eNOS). ADMA has been determined to be an endogenous competitive inhibitor of the endothelial NO-S [8]. Considering the above, ADMA level and endothelial nitric oxide synthase in vascular complications of diabetes mellitus, in particular in diabetic retinopathies, appear to be relevant for investigators.

Study purpose: to study the level of asymmetric dimethylarginine and endothelial nitric oxide synthase at different stages of development of diabetic retinopathy in the experiment.

\section{Materials and methods}

The study was conducted in Wistar white rats of 180 $200 \mathrm{~g}$ weight. According to the tasks, the animals were separated into 2 groups as follows: Group 1 - 60 intact animals, and Group 2 - 60 animals with simulated diabetic retinopathy without further correction.

Type 2 diabetes mellitus and diabetic retinopathy were simulated by means if intraperitoneal administration of Streptozotocin (Sigma, USA) diluted in $0.1 \mathrm{M}$ citrate buffer with $\mathrm{pH} 4.5$ [22]. Streptozotocin dose of $55 \mathrm{mg}$ per $\mathrm{kg}$ of animal weight was divided into two administrations. Streptozotocin administration was preceded by a 28-day diet rich in fats [15].

The animals were withdrawn from the experiment by means of decapitation under brief ether anaesthesia according to the Rules to Perform Works with Use of Experimental Animals approved with Decree of the Ministry of Health of Ukraine No.249 of 01.03.2012 and the Law of Ukraine No.3447-IV, About Animal Protection Against Cruelty (as amended on 15.12.2009 and 16.10.2012).

The animals were withdrawn from the experiment in three stages: Study stage 1: 30th day after commencement of diabetes mellitus simulation; Study stage 2: 60th day after commencement of diabetes mellitus simulation; Study stage 3: 180th day after commencement of diabetes

A

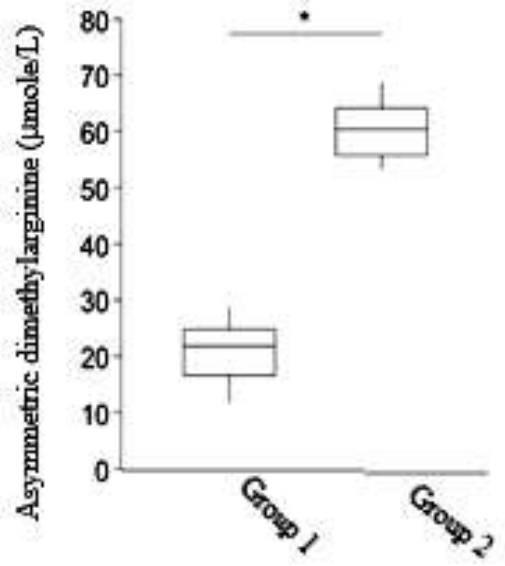

B

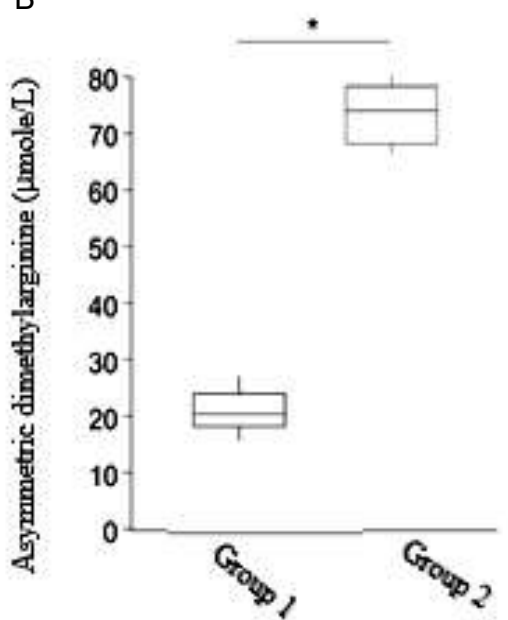

mellitus simulation. The endothelial synthase ( $\mu \mathrm{mol} / \mathrm{L} /$ hour) and ADMA level $(\mu \mathrm{mol} / \mathrm{L})$ were determined with spectrofluorometric technique in blood of the experimental rats.

Prior to application of parametric methods that are based on normality of statistical distribution, we have verified the arrays of numeric data being studied for normality with Shapiro-Wilk's W test. As the numeric data in the samples were normally distributed, we have used Student's parametric criterion. The data obtained are presented in the figures in the form of box diagrams.

\section{Results}

In testing ADMA level at the first stage of our study we have determined its significant (by $65.67 \%$ ) enhancement in the group of simulated diabetic retinopathy $(p<0.001)$. The following findings were obtained at the second stage: an increased level of the studied endothelial dysfunction marker was registered: increase by $71.97 \%$ versus the intact animals $(p<0.001)$ and by $18.6 \%$ versus the experimental uncorrected group $(p<0.001)$. On the 180th day, even more apparent increase in ADMA was revealed in the rats with simulated diabetic retinopathy: compared with findings of Group 1, its level was pathologically increased by $75.85 \%$ $(p<0.001)$. Compared with Stage I findings, ADMA level was higher by $29.85 \%(p<0.001)$, and with Stage II findings, an increase in concentration of endothelial NO-synthase by

Table 1. Dynamics of ADMA ( $\mu \mathrm{mol} / \mathrm{L}$ ) level in the blood of experimental animals with simulated diabetic retinopathy at various study stages $(\mathrm{M} \pm \mathrm{m})$.

\begin{tabular}{|c|c|c|c|}
\hline \multirow{2}{*}{ Groups } & \multicolumn{3}{|c|}{ Stages } \\
\cline { 2 - 4 } & I & II & III \\
\hline Group 1 & $20.81 \pm 1.28$ & $20.80 \pm 0.86$ & $20.82 \pm 1.25$ \\
\hline Group 2 & $60.40 \pm 1.16$ & $74.21 \pm 1.36$ & $86.13 \pm 1.08$ \\
\hline
\end{tabular}

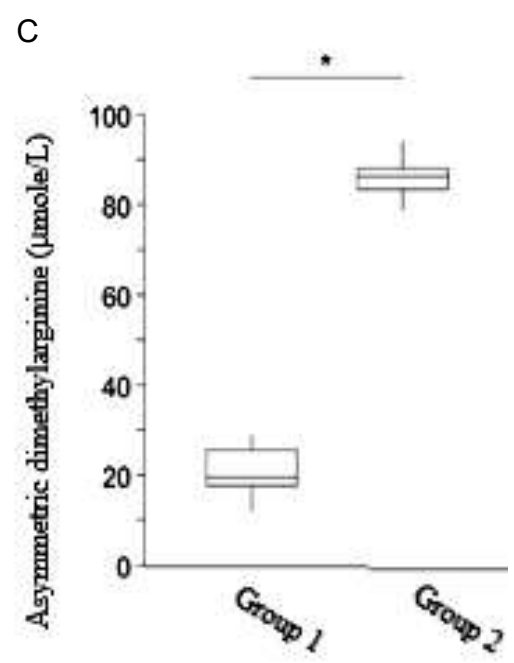

Fig. 1. Comparative indicators of the level of ADMA content in the blood of experimental animals of both groups. A-ADMA concentration $(\mu \mathrm{mol} / \mathrm{L})$ after 30 days; $B$ - after 60 days and C - 180 days after the induction of diabetic retinopathy. * - statistically significant difference between the indicators of the control and experimental groups. 
A

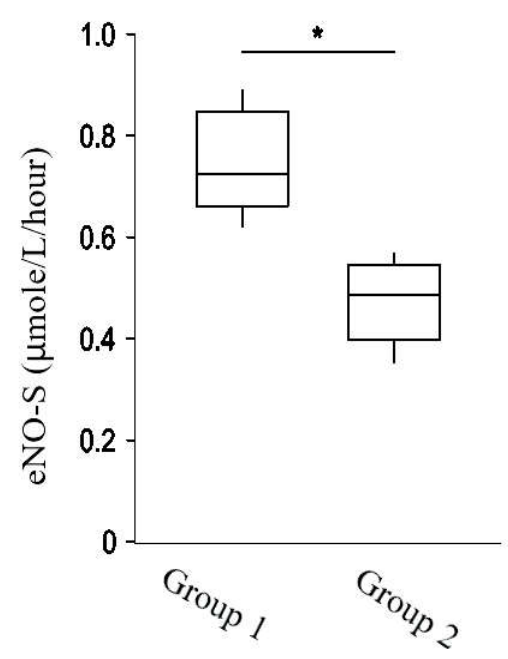

B

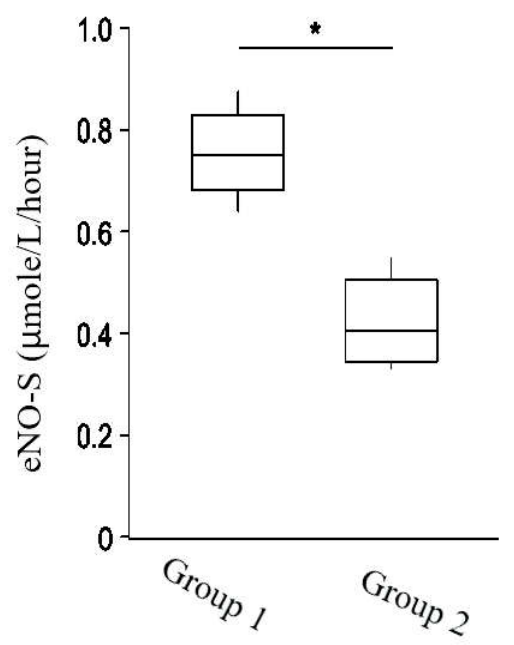

0

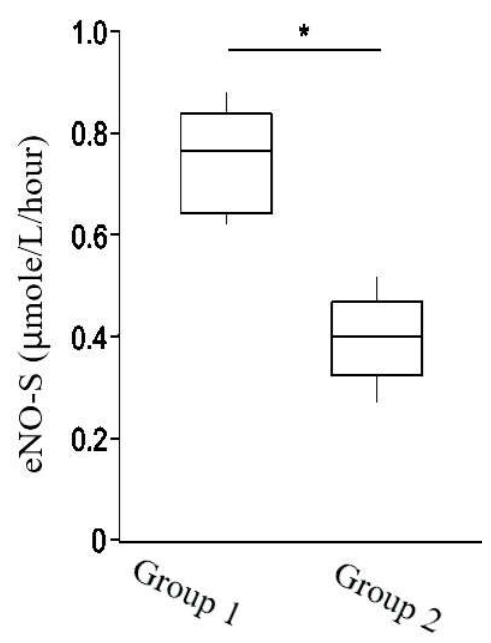

Fig. 2. Comparative parameters of eNO-S activity ( $\mu \mathrm{mol} / \mathrm{L} / \mathrm{hour}$ ) in the blood of experimental animals of both groups. A- distribution of eNO-S level values after 30 days; B - after 60 days and C - 180 days after the induction of diabetic retinopathy. ${ }^{*}$ - statistically significant difference between the indicators of the control and experimental groups.

Table 2. Dynamics of eNO-S ( $\mu \mathrm{mol} / \mathrm{L} /$ hour) activity in the blood of experimental animals with simulated diabetic retinopathy at various study stages $(\mathrm{M} \pm \mathrm{m})$.

\begin{tabular}{|c|c|c|c|}
\hline \multirow{2}{*}{ Groups } & \multicolumn{3}{|c|}{ Stages } \\
\cline { 2 - 4 } & $\mathrm{I}$ & $\mathrm{I}$ & II \\
\hline Group 1 & $0.752 \pm 0.030$ & $0.751 \pm 0.023$ & $0.750 \pm 0.031$ \\
\hline Group 2 & $0.480 \pm 0.021$ & $0.433 \pm 0.020$ & $0.401 \pm 0.022$ \\
\hline
\end{tabular}

$13.83 \%(p<0.001)$ was revealed (Table 1, Fig. 1).

As to NO-synthase activity, we have determined on the 30th day its notable decrease (by $56.25 \%$ ) in the blood of rats with simulated diabetic retinopathy (statistically distinctions at significance level $p<0.001$ ). On the 60th day (Stage II), we have found out that activity of endothelial nitric oxide synthase lowered even more, by $11.63 \%$ compared with findings of the same group at the previous stage $(p<0.05)$, and by $56.25 \%$ than findings of the intact rats $(p<0.001)$. On the 180th day, eNO-S activity deceased by $87.50 \%$ compared with findings of Group 1.

Having reviewed the activity dynamics for the studied enzyme, we have found that it was lower by $20.0 \%(p<0.001)$ compared with the first stage findings and by $7.5 \%$ compared with the second stage (Table 2, Fig. 2).

To summarize the above, we can affirm that our experiment has proved the development of endothelial dysfunction subsequent to investigational diabetic retinopathy as evidenced by apparent increase in ADMA level at each of the study stages. Additionally, we have confirmed the inhibiting effect of asymmetric dimethylarginine on the endothelial NO-synthase activity. As mentioned above, eNO-S activity is a marker of the nitric oxide physiological synthase, and decrease in this appears to be another indicator of the endothelial functional condition.

\section{Discussion}

The key role in regulation of the endothelial function is played by nitric oxide the synthesis of which requires for Larginine amino acid. As mentioned above, asymmetric dimethylarginine is deemed to be an important NOsynthase inhibitor to block connection of L-arginine with the enzyme. Concentration of this inhibitor in blood is variable and depends on multiple reactions both on cellular and tissular levels [13]. Arginine residues in proteins which are catalysed with S-adenosyl methionine-dependent methyltransferases undergo post-translational methylation and are essential for metabolism of the said enzymes. Since the methylation is irreversible, it can be affected only through proteolysis, therefore methylated proteins are highly metabolic [13, 32]. Free ADMA is expressed under proteolysis being induced by intracellular dimethylarginine dimethylaminohydrolase affected by a few factors, mainly the glycated proteins [18].

Inhibition of dimethylarginine dimethylaminohydrolase occurs with depression of NO synthesis and increase in ADMA content $[13,19]$. Once in the blood, approximately $10 \%$ of the total amount of ADMA are partially hydrolysed in cells and partially excreted by kidneys. ADMA affects cells negatively contributing to oxidising stress, shortening telomeres, inhbiting NO release, increasing secretion of Interleukin-8 and monocyte chemotactic factor 1 [2]. Its effect involves the entire body: increased blood pressure, enhanced pulmonary and total peripheral vascular resistances, decreased cardiac output [13, 16]. Such atherogenesis processes like expression of inflammatory and chemotactic cytokines, monocyte adhesion [6, 9, 13], and accumulation of oxidised low-density lipoproteins activate ADMA in macrophages [21]. Patients with the atherosclerosis risk factors such as diabetes mellitus [21, 
34], hypercholesterolemia [5], hyperhomocysteinemia [30, 31], and obesity presented increased ADMA concentrations in blood plasma. This correlates with initial atherosclerosis markers, such as carotid intima-media thickness [13, 38].

ADMA which is a structural analogue of L-arginine depresses activity of all isoforms of NO-synthases thus inhibiting formation of nitric oxide in tissues and blood plasma. It has been proved that ADMA significantly depresses NO synthesis [27, 36]. There is a strong correlation between the levels of nitric oxide in plasma under physiologic conditions which, once broken, result in vascular pathologies [7]. The studies showed that Larginine activates vasomotor reactions in vivo $[3,4,10]$. And this is despite that endogenous L-arginine is 30 times higher in physiologic concentrations in blood plasma than Michaelis-Menten Constant for L-arginine in a NO-synthase catalysed reaction [10, 24, 27]. At first, the effect of L-arginine on vascular tone appeared to be a little paradoxical since NO-synthase was totally saturated with a substrate, and additional effect of exogenous arginine could not affect intensity of the nitric oxide synthesis [3]. A little later, we have found such endogenous analogues of $L$-arginine like $\mathrm{N}$-monomethyl-L-arginine (NMMA), asymmetric N-Ndimethyl-L-arginine (ADMA), and symmetric N-N-dimethylL-arginine (ADMA) [17, 27]. Two of them, ADMA and NMMA are able to inhibit NO-synthase activity $[12,25]$. This allows

\section{References}

[1] Achan, V., Broadhead, M., Malaki, M., Whitley G., Leiper, J., MacAllister, R., \& Vallance, P. (2003). Asymmetric dimethylarginine causes hypertension and cardiac dysfunction in humans and is actively metabolized by dimethylarginine dimethylaminohydrolase. Arterioscler. Thromb. Vasc. Biol., 23(8), 1455-1459. doi: 10.1161/ 01.ATV.0000081742.92006.59

[2] Bode-Boger, S. M., Scalera, F., \& Martens-Lobenlioffer, J. (2005). Asymmetric dimethylarginine (ADMA) accelerates cell senescence. Vasc. Med., 10(1), 65-71. https://doi.org/10.1191/ 1358863x05vm606oa

[3] Boger, R. H. (2004). Asymmetric dimethylarginine, an endogenous inhibitor of nitric oxide synthase, explains the "Larginine paradox" and acts as a novel cardiovascular risk factor. J. Nutr., 134(10), 2842S-2847S. doi: 10.1093/jn/ 134.10.2842S

[4] Boger, R. H., Bode-Boger, S. M., Mugge, A., Kienke, S., Brandes, R., Dwenger, A., \& Frolich, J. C. (1995). Supplementation of hypercholesterolaemic rabbits with $L$-arginine reduces the vascular release of superoxide anions and restores $\mathrm{NO}$ production. Atherosclerosis, 117, 273-284. doi: 10.1016/00219150(95)05582-h

[5] Boger, R. H., Bode-Boger, S. M., Szuba, A., Tsao, P. S., Chan, J. R., Tangphao, O. ... Cooke, J. P. (1998). Asymmetric dimethylarginine (ADMA): a novel risk factor for endothelial dysfunction: its role in hypercholesterolemia. Circulation, 98(18), 1842-1847. doi: 10.1161/01.cir.98.18.1842.

[6] Boger, R. H., Bode-Boger, S. M., Tsao, P. S., Lin, P. S., Chan, J. R., \& Cooke, J. P. (2000). An endogenous inhibitor of nitric oxide synthase regulates endothelial adhesiveness for monocytes. JACC, 36, 2287-2295. doi: 10.1016/s07351097(00)01013-5. to explain the "L-arginine paradox" since higher concentration of the substrate is required for NO-synthase activation with its endogenous inhibitors. ADMA under physiologic conditions is a stronger inhibitor than NMMA as its concentration in blood plasma is 5 times higher [20, 27, 35].

Considering the above, further analysis of the nitric oxide physiological synthesis markers and use of L-arginine for correction of pathological conditions caused by a sharply increased ADMA level in blood is enlightening.

\section{Conclusion}

1. Our study showed impairment of the endothelial functional condition in investigational diabetic retinopathy as evidenced by increased level of ADMA $(p<0.001)$.

2. We have determined a stepwise increase of asymmetric dimethylarginine level in blood of rats with simulated pathology which was apparent in its highest at phase 3 .

3. Pathogenetic effect of increased ADMA on eNO-S activity was verified at all experimental stages.

4. Impairment of physiological nitric oxide synthesis in simulated pathology has been proved as evidenced by reduced activity of endothelial NO-synthase yet on the 30th day with further negative dynamics up to the 180th day ( $p<0.001$ compared with the intact group findings).

[7] Boger, R. H., Cooke, J. P., \& Vallance, P. (2005). ADMA: an emerging cardiovascular risk factor. Vasc. Med., 10, 1, S1S2.

[8] Buryal, V. V. (2014). Role of asymmetric dimethylarginine in formation of pathophysiologic mechanisms for arterial pressure control impairments. Young scientist, 6(9), 142-144.

[9] Chan, J. R., Boger, R. H., Bode-Boger, S. M., Tangphao, O., Tsao, P. S., Blaschke, T. F., \& Cooke, J. P. (2000). Asymmetric dimethylarginine increases mononuclear cell adhesiveness in hypercholesterolemic humans. Arterioscler Thromb Vasc Biol., 20, 1040-1046. https://doi.org/10.1161/01.ATV.20.4.1040

[10] Creager, M. A., Gallagher, S. J., Girerd, X. J., Coleman, S. M., Dzau, V. J. \& Cooke, J. P. (1992). L-Arginine improves endothelium-dependent vasodilation in hypercholesterolemic humans. J. Clin. Invest., 90, 1248-1253.

[11] Eid, H.,M., Amesen, H., Hjerkiim, E. M., Lyberg, T., \& Seljeflot, I. (2004). Relationship between obesity, smoking, and the endogenous nitric oxide synthase inhibitor, asymmetric dimethylarginine. Metabolism, 53(12), 1574-1579. doi.org/ 10.1016/..metabol.2004.06.026

[12] Faraci, F. M., Brian, J. E. J., \& Heistad, D. D. (1995). Response of cerebral blood vessels to an endogenous inhibitor of nitric oxide synthase. Am. J. Physiol., 269, H1522-H1527. doi.org/ 10.1152/ajpheart.1995.269.5.H1522

[13] Galyavich, A. S., \& Gaynutdinov, E. R. (2009). Asymmetric dimethylarginine and nitric oxide metabolism products in patients with acute and chronic forms of coronary heart disease. Cardiovascular therapy and prevention, 8(1), 31-34.

[14] Gavrilova, N. A., \& Tishchenko, O. E. (2011). The impact of sulodexide on the endothelial functional state in patients with diabetes mellitus and diabetic retinopathy. Diabetes Mellitus, 2, 66-68. 
[15] Kaydash, O. A., Ivanov, V. V., Vengerovskyi, A. I., Buyko Ye. Ye., \& Shchepetkin, I. A. (2020) Investigational model of Type 2 diabetes mellitus in rats caused by a diet with high content of fats and low dosage of streptozotocin. The Siberian Medicine Bulletin, 19(2), 41-47.

[16] Kielstein, J. T., Tsikas, D., Fliser, D. (2006). Effects of asymmetric dimethylarginine (ADMA) infusion in humans. Eur. J. Clin. Pharmacol., 62(13), 39-44. doi: 10.1007/s00228-005-0010-1

[17] Leiper, J., \& Vallance, P. (1999). Biological significance of endogenous methylarginines that inhibit nitric oxide synthases. Cardiovasc. Res., 43(3), 542-548. doi.org/10.1016/S00086363(99)00162-5

[18] Lu, C. W., Xiong, Y., \& He, P. (2006). Dimethylarginine dimethylaminohydr olase-2 overexpression improves impaired nitric oxide synthesis of endothelial cells induced by glycated protein. Nitric Oxide: Biology and Chemistry, 16(1):94-103. doi: 10.1016/j.niox.2006.07.006

[19] MacAllister, R. J., Parry, H., Kimoto, M., Ogawa, T., Russell, R. J., Hodson, H., ... Vallance, P. (1996). Regulation of nitric oxide synthesis by dimethylarginine dimethylaminohydrolase. Br. J. Pharmacol., 119(8), 1533-1540. doi: 10.1111/j.14765381.1996.tb16069.x.

[20] Nonaka, S., Tsunoda, M., Imai, K., \& Funatsu, T. (2005). Highperformance liquid chromatographic assay of $N(G)$ monomethyl-L-arginine, $N(G), N(G)$-dimethyl-L-arginine, and $N(G), N(G)$ '-dimethyl-L-arginine using 4-fluoro-7-nitro-2, 1,3benzoxadiazole as a fluorescent reagent. J. Chromatogr., $A$ 1066, 41-45. doi: 10.1016/j.chroma.2005.01.052

[21] Paiva, H., Lehtimaki, T., Laakso, J., Ruokonen, I., Rantalaiho, V., Wirta, O. ... Laaksonen, R. (2003). Plasma concentrations of asymmetric dimethylarginine in type 2 diabetes associate with glycemic control and glomerular filtration rate but not with risk factors of vasculopathy. Metabolism, 52, 303-307. doi: 10.1053/meta.2003.50048

[22] Pasechnikova, N. V., \& Moroz, O. A. (2015). Protective action of quercetin and lipoate on functional groups of retinal proteins under simulated diabetes. Journal of Ophthalmology, 3, 76-81.

[23] Perticone F., Sciacqua A., Maio R., Perticone, M., Maas, R., Boger, R. H. ... Zoccali, C. (2005). Asymmetric dimethylarginine, L-arginine, and endothelial dysfunction in essential hypertension. J. Am. Coll. Cardiol., 46, 518-523.

[24] Pollock, J. S., Forstermann, U., Mitchell, J. A., Warner, T. D., Schmidt, H. H., Nakane, M., \& Murad, F. (1991). Purification and characterization of particulate endothelium-derived relaxing factor synthase from cultured and native bovine aortic endothelial cells. Proc. Natl. Acad. Sci. U.S.A., 88, 1048010484. doi: $10.1073 /$ pnas.88.23.10480

[25] Rees, D. D., Palmer, R. M., Schulz, R., Hodson, H. F., \& Moncada, S. (1990). Characterization of three inhibitors of endothelial nitric oxide synthase in vitro and in vivo. Br. J. Pharmacol., 101(3), 746-752. doi: 10.1111/j.1476-5381.1990.tb14151.x

[26] Rizzoni, D., Porteri, E., Castellano, M., Bettoni, G., Muiesan, M. L., Tiberio, G. ... Agabiti-Rosei, E. (1998). Endothelial Dysfunction in Hypertension Is Independent From the Etiology and From Vascular Structure. Hypertension, 31, 335-341. doi: 10.1161/01.hyp.31.1.335
[27] Rodionov, R. N., Blokhin, I. O., Galagudza, M. M., Shlyakhto, E. V., \& Lentz, S. R. (2008). Asymmetric dimethylarginine and its role in aetiology and pathogenesis of cardiovascular diseases. Arterial hypertension, 4, 306-314.

[28] Saitoh, M., Osanai, T., Kamada, T., Matsunaga, T., Ishizaka, H., Hanada, H., \& Okumura, K. (2003). High plasma level of asymmetric dimethylarginine in patients with acutely exacerbated congestive heart failure: role in reduction of plasma nitric oxide level. Heart Vessels, 18, 177-182. doi: 10.1007/s00380-003-0715-y

[29] Smirnova, I. V., Kajstura, M., Sawamura, T., \& Goligorsky, M. S. (2004). Asymmetric dimethylarginine upregulates TOX-1 in activated macrophages: role in foam cell formation. Am. J. Physiol. Heart Circ. Physiol., 287(2), H782-9. doi: 10.1152/ ajpheart.00822.2003.

[30] Stuhlinger, M. C., Oka, R. K., Graf, E. Ë., Schmolzer, I., Upson, B. M., Kapoor, O. ... Cooke, J. P. (2003). Endothelial dysfunction induced by hyperhomocyst (e) inemia: role of asymmetric dimethylarginine. Circulation, 108(8), 933-938. doi: 10.1161/ 01.CIR.0000085067.55901.89

[31] Stuhlinger, M. C., Tsao, P. S., Her, J. H., Kimoto, M., Balint, R. F. \& Cooke, J. P. (2001). Homocysteine impairs the nitric oxide synthase pathway: role of asymmetric dimethylarginine. Circulation, 104(21), 2569-2575. doi: 10.1161/hc4601.098514.

[32] Teerlink, T. (2005). ADMA metabolism and clearance. Vasc. Med., 10(1), 73-81. doi: 10.1191/1358863x05vm597oa.

[33] Teerlink, T. (2005). Measurement of asymmetric dimethylarginine in plasma: methodological considerations and clinical relevance. Clin. Chem. Lab. Med., 43, 1130-1138. doi: 10.1515/ CCLM.2005.197.

[34] Tin, K. Y., Ito, A., Asagami, T., Tsao, P. S., Adimoolam, S., Kimoto, M. ... Cooke, J. P. (2002). Impaired nitric oxide synthase pathway in diabetes mellitus: role of asymmetric dimethylarginine and dimethylarginine dimethylaminohydrolase. Circulation, 106, 987-992. doi: 10.1161/ 01.cir.0000027109.14149.67

[35] Ueno, S., Morino, H., Sano, A., \& Kakimoto Y. (1990). Purification and characterization of D-3-aminoisobutyrate-pyruvate aminotransferase from rat liver. Biochim. Biophys. Acta., 1033(2), 169-175. https://doi.org/10.1016/03044165(90)90008-K

[36] Vallance, P., Leone, A., Calver, A., Collier, J., \& Moncada, S. (1992). Accumulation of an endogenous inhibitor of nitric oxide synthesis in chronic renal failure. Lancet, 339(8793), 572575. doi: 10.1016/0140-6736(92)90865-z

[37] Vallance, P., Leone, A., Calver, A., Collier, J., \& Moncada, S. (1992). Endogenous dimethylarginine as an inhibitor of nitric oxide synthesis. J. Cardiovasc. Pharmacol., 20, 12, 60-62. doi: 10.1097/00005344-199204002-00018.

[38] Zoccali, C., Benedetto, F. A., Maas, R., Mallamaci, F., Tripepi, G., Malatino, L. S., \& Boger, R. (2002). Asymmetric dimethylarginine, C-reactive protein, and carotid intima-media thickness in endstage renal disease. J. Am. Soc. Nephrol., 13, 490-496.

[39] Zhloba, A. A. (2007). Asymmetric dimethylarginine as a mediator and marker for endothelial dysfunction development. Arterial hypertension, 13(2), 119-127.

\section{ЗМІНА РІВНЯ АСИМЕТРИЧНОГО ДИМЕТИЛАРГІНІНА І ЕНДОТЕЛІАЛЬНОЇ СИНТАЗИ ОКСИДУ АЗОТУ В ПАТОГЕНЕЗІ ЕКСПЕРИМЕНТАЛЬНОЇ ДІАБЕТИЧНОЇ РЕТИНОПАТІЇ}

Сірман Я.В., Савицький І.В., Прейс Н.І.

У виникненні та прогресуванні діабетичної ретинопатії важливу роль відіграє ендотеліальна дисфункція, пов'язана з порушенням виділення оксиду азоту. Доведено, що важливу роль при цьому відіграє зниження активності ендотеліальної NO-синтази (eNO-S), інгібітором якої є асиметричний диметиларгінін (ADMA). Мета дослідження: вивчити рівень 
асиметричного диметиіларгініна і ендотеліальної синтази оксиду азоту на різних етапах розвитку діабетичної ретинопатії в експерименті. Дослідження проводили на білих щурах лінії Вістар масою 180-200 г. Відповідно до завдання дослідження тварини були розділені на 2 групи: 1 група - 60 інтактних тварин, 2 група - 60 тварин з моделюванням діабетичної ретинопатії без подальшої корекції. Цукровий діабет 2 типу та діабетичну ретинопатію моделювали внутрішньоочеревинним введенням стрептозотоцину (Sigma, США), розведеного в 0,1M цитратному буфрері з рH=4,5. Дозу стрептозотоцину 55 ме на ка ваги тварини поділяли на 2 прийоми. Прийому стрептозотоцину передувала 28-добова дієта, багата жирами. Наше дослідження показало порушення фрункціонального стану ендотелію при досліджуваній діабетичній ретинопатії, про що свідчить підвищений рівень ADMA (p<0,001). Ми визначили ступеневе підвищення рівня асиметричного диметиларгініна в крові щурів із модульованою патологією, максимальний прояв котрого спостерігалось у третій фразі. Патогенетичний ефект підвищеного ADMA на активність еNO-S підтверджений на всіх етапах експерименту. Порушення фізіологічного синтезу оксиду азоту при патології підтверджується зниженням активності ендотеліальної NO-синтази ще на 30 добу з подальшою негативною динамікою до 180 дня ( $p<0,001$ у порівнянні з даними інтактної групи).

Ключові слова: діабетична ретинопатія, ендотеліальна дисффункція, асиметричний диметиларгінін, ендотеліальна NOсинтаза, порівняльний опис.

\section{ИЗМЕНЕНИЕ УРОВНЯ АСИММЕТРИЧНОГО ДИМЕТИЛАРГИНИНА И ЭНДОТЕЛИАЛЬНОЙ СИНТАЗЫ ОКСИДА АЗОТА В ПАТОГЕНЕЗЕ ЭКСПЕРИМЕНТАЛЬНОЙ ДИАБЕТИЧЕСКОЙ РЕТИНОПАТИИ \\ Сирман Я.В., Савицкий И.В., Прейс Н.И.}

В возникновении и прогрессировании диабетической ретинопатии важную роль играет эндотелиальная диссрункция, связанная с нарушением выделения оксида азота. Доказано, что важную роль при этом играет снижение активности эндотелиальной NO-синтазы (eNO-S), ингибитором которой является асимметричный диметиларгинин (ADMA). Цель исследования: изучить уровень асимметричного диметиларгинина и эндотелиальной синтазы оксида азота на различных этапах развития диабетической ретинопатии в эксперименте. Исследование проводили на белых крысах линии Вистар массой 180-200 е. В соответствии с заданием исследования животные были разделены на 2 группы: 1 группа - 60 интактных животных, 2 группа - 60 животных с моделированной диабетической ретинопатией без дальнейшей коррекции. Сахарный диабет 2 типа и диабетическую ретинопатию моделировали внутрибрюшным введением стрептозотоцина (Sigma, США), разведенным в 0,1M цитратном буфере с $\mathrm{pH}=4,5$. Дозу стрептозотоцина 55 мг на кг веса животного разделяли на два приема. Приему стрептозотоцина предшествовала 28-дневная диета, богатая жирами. Наше исследование показало нарушение фрункционального состояния эндотелия при диабетической ретинопатии, о чем свидетельствовал повышенный уровень ADMA ( $p<0,001)$. Мы определили ступенчатое повышение уровня асимметричного диметиларгинина в крови крыс с моделируемой патологией, максимальное проявление которого наблюдалось в третьей фразе. Патогенетический эфффект повышенного ADMA на активность еNO-S подтвержден на всех этапах эксперимента. Нарушение фризиологического синтеза оксида азота в моделируемой патологии подтверждается снижением активности эндотелиальной NO-синтазы еще на 30-е сутки с отрицательной динамикой до 180 дня ( $p<0,001$ по сравнению с данными интактной группы).

Ключевые слова: диабетическая ретинопатия, эндотелиальная дисфункция, асимметричный диметиларгинин, эндотелиальная NO-синтаза, сравнительное описание. 